\title{
DERECHO DISCIPLINARIO Y SEGURIDAD
}

\section{JURÍDICA}

\author{
Prof. Dr. José Rafael Guillamón Fernández \\ Defensor Universitario UNED \\ Prof. Dr. Eugenio Baraja Rodríguez \\ Defensor Universitario UVA \\ Profa. Dra. María Acale Sánchez \\ Defensora Universitaria UCA
}

\section{I.DERECHO DISCIPLINARIO UNIVERSITARIO}

La potestad sancionadora de la Administración tiene su reconocimiento constitucional en el art. 25, donde además se señala una clara limitación máxima en cuanto a la naturaleza de las sanciones a imponer, que no podrán implicar directa o subsidiariamente privación de libertad. Pero poco más ilustra el precepto al respecto. Este reconocimiento lleva implícito otro: y es el de la autosuficiencia sancionadora de la Administración que, en primera instancia, se vale por si sola para sancionar a su personal, sin necesidad de la intervención judicial. De ahí precisamente que se pueda concluir que el reconocimiento de esa potestad pone en riesgo el principio de jurisdiccionalidad de la sanción, en virtud del cual, son los juzgados y tribunales los que las imponen, ya que en el ámbito interno de la Administración, si el sancionado no recurre la sanción que le ha 
sido impuesta, cobrará firmeza sin intervención jurisdiccional. Por este motivo, dada la excepcionalidad que supone que las sanciones no sean impuestas por los juzgados y Tribunales, es preciso controlar esa potestad y mantenerla siempre al amparo del principio de legalidad.

A partir de este reconocimiento, es tradicional separar la fundamentación de esta potestad sancionadora desde el punto de vista subjetivo, según las infracciones y sanciones de que se trate, vinculen a toda la ciudadanía (supremacía general) o a un sector específico de ella que se encuentre en contacto más intenso con la Administración (supremacía especial) ${ }^{1}$. En este sentido, se comprende que el acceso al empleo público (ya sea por oposición o por contrato) lleva aparejado la imposición al trabajador/a de una serie de deberes que debe respetar durante su actuación pues a partir de ese momento, la ciudadanía identifica a la Administración con el personal a su servicio. El incumplimiento de los mismos permite a la Administración sancionarle, "con efectos de exclusiva trascendencia ad intra y con una considerable merma de las garantías para el expedientado"2.

Hoy, con el proceso de maduración que ha sufrido la sociedad española, y de su mano, con el proceso de maduración que ha sufrido el ordenamiento jurídico español ${ }^{3}$,

\footnotetext{
${ }^{1}$ Y así, la STS de Justicia de Castilla León (Sala de lo contencioso-administrativo) 2226/2014, de 31 de octubre JUR 2015/26624 parte de que en efecto, "en principio, no son totalmente equiparables -art. 127.3 LRJPAC- la responsabilidad por sanciones administrativas o ad extra y la disciplinaria o ad intra, ésta última aplicable al caso de los funcionarios; siendo más intensa la potestas de la Administración en la segunda que en la primera, por la naturaleza de relación de sujeción especial existente entre "empleador" y "empleado" que supone la función pública; y es evidente. que, por mucho que se desee, la Administración, que se rige por el principio de objetividad - art. 103 CE-, nunca, jamás, será un Tribunal de Justicia, que se rige por la justicia y la imparcialidad - artículo 117 de la Ley de Leyes".

2 Tomás Quintana López, "La potestad disciplinaria de la Administración sobre los empleados públicos", en Documentación Administrativa, 2009/282-283, p. 324.

3 Proceso durante el cual se ha dejado a un lado el "buen nombre" de la Administración pública o la violación del deber de obediencia como fundamenta de la sanción, lo que difícilmente permitía una configuración material del injusto administrativo. Vid. por todos. Cristina Méndez Rodríguez, "Sobre la naturaleza de los delitos de los funcionarios públicos en el ejercicio de sus cargos", en Estudios jurídicos en Memoria del Prof. Dr. D. José Ramón Casabó Ruiz, VII, ed. Servicio de Publicaciones de la Universidad de Valencia, Valencia, 1997 pp. 349 y ss.
} 
pierde fuerza la clásica separación del fundamento del derecho sancionador según se trate de una situación de supremacía general o especial, pues en ambos casos se tiende a identificar una serie de bienes jurídicos de titularidad colectiva cuya protección fundamenta la infracción y el ataque a los mismos justifica la imposición de la correspondiente sanción: la Administración pública es por tanto una entidad que administra bienes públicos, cumpliendo así las funciones que la Constitución le encomienda, desde la cual es fácil deducir su finalidad prestacional, colocada en cualquier caso al servicio de la ciudadanía. En este sentido afirma el art. 103 de la Constitución que "la Administración pública sirve con objetividad los intereses generales y actúa de acuerdo con los principios de eficacia, jerarquía, descentralización, desconcentración y coordinación, con sometimiento pleno a la ley y al Derecho".

Pues bien, en este contexto ha de situarse la potestad que tiene la Universidad para sancionar a trabajadores/as y estudiantes cuando mediante la realización de conductas contrarias a la legalidad universitaria vigente, afecten a los bienes jurídicos y a las funciones que está llamada a desempeñar, garantizando de paso una convivencia pacífica. En este sentido, hasta la aprobación de la Ley 7/2007, de 12 de abril, del Estatuto Básico del Empleado Público (en adelante EBEP), el marco normativo sancionador en el ámbito del trabajo universitario estaba disperso entre el Estatuto de los trabajadores y los correspondientes Convenios colectivos, para los/as trabajadores/as laborales ${ }^{4}$ y el Real Decreto 33/1986, de 10 de enero, por el que se aprueba el Reglamento del Régimen Disciplinario de los Funcionarios de la Administración del Estado. Se daba la circunstancia además de que por la fecha, se trataba de un texto anterior a la Ley 30/1992,

\footnotetext{
${ }^{4}$ Téngase en consideración que el BOE de 24 de octubre de 2015 ha publicado el Real Decreto Legislativo $2 / 2015$, de 23 de octubre, por el que se aprueba el texto refundido de la Ley del Estatuto de los Trabajadores. Se trata de un texto que carece de mención alguna entorno al día de su entrada en vigor, por lo que en atención a lo establecido en el art. 2 del Código Civil, ha de entender que entró en vigor " $a$ los veinte días de su completa publicación en el Boletín Oficial del Estado".
} 
de 26 de noviembre, de Régimen Jurídico de las Administraciones Públicas y del Procedimiento Administrativo Común (en adelante LRJAPPAC), que establecía (y establece aún) con carácter general en sus arts. 127 y siguientes, dentro del Título IX “de la potestad sancionadora" los principios que la rigen (principios de legalidad, irretroactividad, tipicidad, responsabilidad, proporcionalidad, non bis in idem $)^{5}$.

Finalmente, los arts. 93 y ss del EBEP contienen un régimen disciplinario que se aplica a todos los trabajadores de la Administración pública, con independencia de que se trate de funcionarios de carrera o de personal laboral. En particular, el art. 2 señala que ese Estatuto es de aplicación al personal funcionario y en lo que proceda al personal laboral al servicio, entre otras, de las "Universidades públicas"'. Ello con independencia

\begin{abstract}
${ }^{5}$ Todavía en vigor, hasta que lo hagan el próximo 1 de octubre las Leyes 39/2015, de 1 de octubre, del Procedimiento Administrativo Común de las Administraciones Públicas y la Ley 40/2015, de 1 de octubre, de Régimen Jurídico del Sector Público. El estudio ambas disposiciones sin duda alguna exceden los límites de este trabajo, no obstante, es necesario señalar que a diferencia de la regulación actual, en la que la LRJAPPAC incluye los principios que rigen la potestad sancionadora de la Administración, en el ámbito de estos nuevas leyes de carácter administrativo se lleva a cabo una separación, de forma que esos principios -que en términos generales siguen siendo los mismos- no se incluyen en la Ley 39/2015, del Procedimiento Administrativo Común, sino en la 40/2015, de Régimen Jurídico del Sector Público en la medida en que según se explica en el Preámbulo de la primera de las Leyes citadas: "este planteamiento responde a uno de los objetivos que persigue esta Ley, la simplificación de los procedimientos administrativos y su integración como especialidades en el procedimiento administrativo común, contribuyendo así a aumentar la seguridad jurídica. De acuerdo con la sistemática seguida, los principios generales de la potestad sancionadora y de la responsabilidad patrimonial de las Administraciones Públicas, en cuanto que atañen a aspectos más orgánicos que procedimentales, se regulan en la Ley de Régimen Jurídico del Sector Público".
\end{abstract}

${ }^{6}$ Las Universidades privadas se rigen por el Estatuto de los Trabajadores. Puede verse la STSJ de Castilla y León $826 / 2002$, de 1 de octubre AS/2002/2751, en la que se considera procedente el despido un varios profesores de la Universidad SEK falta muy grave de quebrantamiento de la buena fue contractual, por lo que se le impone la sanción de despido disciplinario: "Es en dicho punto, donde debe centrarse la existencia, de la transgresión de la buena fe contractual denunciada por la demandada, con amparo en el artículo 54.2.d) ET, y la propia jurisprudencia que la desarrolla, en el sentido de que: en interpretación del artículo 54.2.d) ET, la buena fe contractual es consustancial al contrato de trabajo, en cuanto por su naturaleza sinalagmática general derechos y deberes recíprocos. El deber de mutua fidelidad entre empresario y trabajador es una exigencia de comportamiento ético jurídicamente exigible y protegido en el ámbito contractual, y la deslealtad implica siempre una conducta contraria a la que habitualmente debe observar el trabajador, respecto de la empresa, como consecuencia del postulado de fidelidad (entre otras SSTS 22 de mayo de 1986 [RJ 1986, 2609] y 26 de enero de 1987 [RJ 1987, 130]). Es conforme a dicha doctrina que entendemos, que siendo respetables y aceptables en principio las críticas de los actores en el ámbito interno de la institución universitaria a la que pertenecían, al darles una trascendencia y publicidad sesgada, indebida y con unas claras repercusiones negativas para la demandada, que no podían ni debían 
de que según establece el número 4 del art. 93, "el régimen disciplinario del personal laboral se regirá, en lo no previsto en el presente Título, por la legislación laboral"”. De esta disposición, como se señalará posteriormente, se desprenden todavía situaciones que en el marco del EBEP causan inseguridad jurídica en materia sancionadora, así como diferencia de trato según la condición laboral/funcionarial del/a trabajador/a. La unificación normativa de la relación laboral del personal al servicio de las Administraciones públicas ha contribuido a subrayar el dato objetivo de que cuando se sanciona a un empleado público por la realización de un acto contrario al derecho universitario, se hace por menoscabar los principios, fines y funciones que la Administración en general y la Universidad en particular desempeña ${ }^{8}$, sin prestar atención a la vieja teoría de la infracción de los deberes inherentes al cargo público.

desconocer, procede, rechazando en su totalidad el recurso interpuesto, la íntegra confirmación de la sentencia de instancia". Como puede apreciarse, si estos hechos se hubieran llevado a cabo en el seno de una Universidad pública, hubieran llevado aparejados una sanción no tan grave.

${ }^{7}$ Sobre el régimen disciplinario a aplicar al personal laboral de la Universidad puede verse la Sentencia del Juzgado de lo Social de Vitoria 29/2012, de 26 de enero AS/2012/1805. Se trata de un representante sindical, personal laboral de la UPV sancionado por la Universidad por una infracción grave de acoso sexual por regalarle a la Vicegerente una caja de contenido indudablemente sexual. El Juzgado de lo Social anula la sanción impuesta al trabajador. Lo que ahora interesa es la afirmación que allí se hace sobre el derecho sancionador aplicable al personal laboral: "La última de las causas de nulidad de la sanción que se invoca en la demanda es la de falta de tipicidad de la misma, al no venir contemplado el régimen disciplinario en el III Convenio Colectivo del Personal de Administración y Servicios Laboral de la UPV/ENU, aportado a los autos, cuestionando la aplicación a tales efectos del el artículo 95.2 b) de la_Ley $7 / 2007$, de 12 de abril (RCL 2007, 768), Estatuto Básico del Empleado Público. Ciertamente, la citada norma colectiva no contempla regulación ninguna del régimen disciplinario del personal incluido en su ámbito de aplicación personal, vacío regulador que, sin embargo, no excluye ni impide la aplicación de las normas legales que imperativamente deban contemplarse. En tal sentido, la referida Ley 7/2007 extiende su ámbito de aplicación, además de al personal funcionario, al personal laboral en lo que proceda al servicio, en lo que aquí interesa, de las Universidades Públicas (artículo 2.1). El Título VII de dicha Ley regula el régimen disciplinario aplicable a los empleados públicos incluyendo expresamente al personal laboral (artículo 93) $y$, en concreto, el número 4 de dicho precepto dispone "El régimen disciplinario del personal laboral se regirá, en lo no previsto en el presente Título, por la legislación laboral", por lo que una elemental interpretación literal permite entender con claridad que, a sensu contrario, en lo previsto por dicho Título, será de aplicación lo dispuesto en él".

Vid. también la STSJ de Galicia (Sala de lo Social) 2547/2011, de 3 de mayo JUR 2011/207677.

${ }^{8}$ Esta es la línea que sigue el Código penal español, en cuyo articulado es tradición encontrar un artículo como el actual art. 24.2 en el que se señala que "se considerará funcionario público todo el que por disposición inmediata de la ley o por elección o por nombramiento de autoridad competente participe en 
Recientemente ha sido publicado en el BOE de 31 de octubre el Real Decreto Legislativo 5/2015, de 30 de octubre, por el que se aprueba el texto refundido de la Ley del Estatuto Básico del Empleado Público cuyas disposiciones finales muestras que no va a entrar en vigor en poco tiempo ${ }^{9}$. En lo que aquí interesa, la nueva ley no ha incorporado cambio alguno. En efecto, el art. 95 sigue postergando a un ulterior desarrollo legal el señalamiento del catálogo de infracciones graves y leves, en los mismos términos que lo hacen los todavía vigentes artículos del EBEP.

A pesar del avance en seguridad jurídica que supuso la entrada en vigor del EBEP que, como se ha visto, no se ha alcanzado completamente, pues se podía dar la circunstancias de que a igualdad de trabajo realizado (la docencia, por ejemplo), la responsabilidad en la que incurría el/a trabajador/a cambiaba según se tratara de un funcionario de carrera o de un trabajador laboral ${ }^{10}$, al día de hoy el derecho disciplinario universitario sigue lastrado por la falta de seguridad jurídica existente en el ámbito del alumnado. En efecto, el Estatuto del Estudiante Universitario (en adelante EEU),

el ejercicio de funciones públicas". Se trata de una definición nada formalista, y sí muy práctica que tiene en consideración como eje el ejercicio de funciones públicas (requisito objetivo) tras haber incorporado a las mismas por las vías tasadas de nombramiento de la autoridad competente, por elección o por disposición inmediata de la ley (requisito subjetivo). Vid. María Acale Sánchez, "Delitos contra la Administración pública. Elementos comunes", en Juan M. Terradillos Basoco (coord.), Memento penal de empresas 2004-2005, ed. Francis Lefebvre, Madrid, 2005, pp.579 y ss.

9 Disposición final cuarta. Entrada en vigor.

"1. Lo establecido en los capítulos II y III del título III, excepto el artículo 25.2, y en el capítulo III del título V producirá efectos a partir de la entrada en vigor de las leyes de Función Pública que se dicten en desarrollo de este Estatuto.

La disposición final tercera del presente Estatuto producirá efectos en cada Administración Pública a partir de la entrada en vigor del capítulo III del título III con la aprobación de las leyes de Función Pública de las Administraciones Públicas que se dicten en desarrollo de este Estatuto. Hasta que se hagan efectivos esos supuestos la autorización o denegación de compatibilidades continuará rigiéndose por la actual normativa.

2. Hasta que se dicten las leyes de Función Pública y las normas reglamentarias de desarrollo se mantendrán en vigor en cada Administración Pública las normas vigentes sobre ordenación, planificación y gestión de recursos humanos en tanto no se opongan a lo establecido en este Estatuto".

10 Vid. al respecto: Diego Cámara del Portillo, "El régimen disciplinario del personal al servicio de la Administración universitaria y del alumnado", en Carolina Blasco Delgado (coorda.), Estudios sobre el régimen jurídico universitario (Jornadas de Secretarios Generales de Universidades Públicas), ed. Universidad de Burgos, Burgos, 2006, pp. 185 y ss. 
aprobado a través del Real Decreto 1781/2010, de 30 de diciembre, establece en su disposición adicional segunda que:

“El Gobierno presentará a las Cortes Generales, en el plazo de un año a partir de la entrada en vigor del presente Real Decreto, un proyecto de ley reguladora de la potestad disciplinaria, en donde se contendrá la tipificación de infracciones, sanciones y medidas complementarias del régimen sancionador para los estudiantes universitarios de acuerdo con el principio de proporcionalidad. De igual modo, en dicho proyecto de ley, se procederá a la adaptación de los principios del procedimiento administrativo sancionador a las especificidades del ámbito universitario, de manera que garantice los derechos de defensa del estudiante y la eficacia en el desarrollo del procedimiento".

Más de cinco años después, ese Estatuto sigue sin desarrollo, lo que hace necesario todavía recurrir al Decreto de 8 de septiembre de 1954, por el que se aprueba el Reglamento de disciplina académica de los Centros Oficiales de Enseñanza Superior y de Enseñanzas Técnica, dependiente del Ministerio de Educación Nacional, causando con ello enormes distorsiones, en la medida en que obliga a las Universidades a bregar con una disposición que viene firmada por Francisco Franco.

Eso sí, al final de la última Legislatura socialista se estuvo trabajando en el texto del Proyecto de Ley de Convivencia y Disciplina Académica en la Enseñanza Universitaria, que no llegó a convertirse en ley. De su nombre se deduce ya el interés que se prestaba más que a la imposición de sanciones por la desobediencia a una norma, o por la falta de respeto a la institución, a la necesidad de hacer partícipes a los miembros de la comunidad universitaria en la idea de convivencia ordenada; de esto se desprenden una 
multitud de consecuencias, entre las que cabría resaltar que el respeto a los bienes jurídicos debe estimular el sentido de responsabilidad de todos sus miembros, como presupuesto necesario para la realización de los fines de la actividad universitaria.

Es interesante resaltar a los efectos que aquí se persiguen (el estudio de la potestad disciplinaria y la seguridad jurídica) que el Proyecto de ley nacía con la intención de ser aplicado a "cuantas personas formen parte de la comunidad universitaria", y a lo largo de su articulado se establecían las bases para la construcción de un modelo de convivencia entre todos esos colectivos; el esfuerzo debe ser valorado muy positivamente pues poco sentido tendría aprobar una ley sobre "convivencia" si no se incluyen en su interior todas las personas y todos los colectivos llamados a "convivir". Ahora bien, una vez identificados de esta forma los colectivos destinatarios de la misma, el art. 3 separaba el régimen disciplinario de unos y a otros.

Así, allí se establecía que "el personal al servicio de las universidades se rige por lo establecido en el EBEP. No obstante, les será plenamente aplicable el régimen establecido en el art. XX acerca de la extinción de responsabilidad mediante procedimientos de mediación", mientras que la letra b) señalaba que "las personas que ostenten la condición de estudiantes se rigen por lo dispuesto en el Título cuarto de la presente ley". De esta forma se ponían de manifiesto dos cosas: por una parte, la intención del pre-legislador de alargar la validez de la mediación como vía para solventar conflictos que impliquen a PDI o PAS; pero también que el régimen disciplinario de ambos colectivos y el diseñado para el alumnado, debía separarse, porque la responsabilidad disciplinaria de los dos primeros colectivos tiene que partir de la infracción de los deberes propios del cargo público que desempeñan, que no constriñen sin embargo al alumnado: de haberse equiparado el tratamiento sancionador, se habría perjudicado ampliamente a 
estos últimos, por exigirles lo mismo que a quienes asumen con su actuación la representación de la propia Administración.

Durante esta legislatura a cuyo término acabamos de asistir, no ha habido tiempo para aprobar el desarrollo reglamentario del EEU, a pesar de la amplia actividad desplegada por el dimitido Ministro de Educación Wert, que ha afectado de forma profunda al modelo de Universidad española (Real Decreto 43/2015, de 2 de febrero, por el que se modifica el Real Decreto 1393/2007, de 29 de octubre, por el que se establece la ordenación de las enseñanzas universitarias oficiales; Real Decreto 415/2015, de 29 de mayo, (BOE de 17 de junio) de modificación del R.D. por el que se modifica el R.D. 1312/2007, por el que se establece la acreditación nacional para el acceso a los cuerpos docentes universitarios; Real Decreto 420/2015, de 29 de mayo, de creación, reconocimiento, autorización y acreditación de universidades y centros universitarios). Ambos datos ponen de manifiesto la existencia de un acuerdo tácito en virtud del cual no se ha querido entrar a desarrollar el EEU en este punto y sí en otras materias: cuestión de prioridades políticas. Este hecho ha influido considerablemente en las distintas normas que en el seno de cada Universidad se han venido aprobando para regular la potestad disciplinaria sobre el alumnado, cubriendo en cada una de ellas el vacío normativo general $^{11}$.

\footnotetext{
${ }^{11}$ Pueden verse entre otros el Reglamento disciplinario de los estudiantes de la Universidad Europea de Madrid (que no está fechado) y que pone la atención en la necesidad de garantizar la convivencia universitaria; la normativa de Régimen disciplinario de los estudiantes de la Universidad Internacional de Catalunya de 30 de septiembre de 2008 (que incide también en la necesidad de "garantizar la convivencia en la Universidad y el correcto desarrollo de sus funciones docentes e investigadoras"), así como la Instrucción Informativa sobre régimen jurídico y procedimiento disciplinario de aplicación a los alumnos de la Universidad Carlos III de Madrid (sin fechar); el Reglamento de Régimen Disciplinario de los alumnos colegiados/residentes de la Universidad de La Laguna de 15 de febrero de 2007; el Reglamento de Régimen disciplinario de los estudiantes de la Universidad Rovira i Virgili, de 18 de diciembre de 2014, o el Acuerdo del Consejo de Gobierno de la Universidad Pompeu Fabra de 18 de julio de 20912 sobre "Régimen disciplinario de los estudiantes".
} 
Pues bien, si este es el desolador panorama que presenta la potestad disciplinaria en el ámbito de las Universidades públicas, no más consolador es el de las Universidades privadas; en efecto, las sanciones a imponer al Personal Docente e Investigador y el Personal de Administración y Servicios son las que con carácter general señala el Estatuto de los Trabajadores, que serán recurribles ante los tribunales de lo social. Así, por ejemplo, la STS de Justicia de Castilla y León 826/2002, de 1 de octubre castiga a unos profesores con la sanción de despido disciplinario por hablar mal de la "empresa", cuando si se hubiera tratado de una Universidad pública, la infracción daría lugar a una sanción disciplinaria. Mayor indefinición existe en torno al régimen sancionador del alumnado de estas Universidades, pues de no estar de acuerdo con la sanción que le imponga la "empresa", no le queda más remedio que recurrir a la Ley de Consumidores y Usuarios, en la que difícilmente puede encontrar una protección específica el derecho a la educación.

\section{PRINCIPIOS GENERALES DEL DERECHO DISCIPLINARIO EN LA}

\section{UNIVERSIDAD}

\section{II.1Principios generales}

\section{II.1.1 Finalidad de la potestad disciplinaria}

El art. 94.1 EBEP establece que la finalidad de la sanción disciplinaria es la corrección "del personal a su servicio" por las conductas ilícitas que lleven a cabo "en el ejercicio de sus funciones y cargos", añadiendo "sin perjuicio de la responsabilidad 
patrimonial o penal que pudieran derivarse de tales infracciones" ${ }^{\prime 12}$. Esa referencia a las finalidades "correctivas" de la sanción disciplinaria debe ser criticada. En efecto, las sanciones no pueden tener otra finalidad que la de castigar al sujeto por el ilícito cometido. Incorporar la idea de la "corrección” en este ámbito no aporta nada, sobre todo si se tiene en consideración que se trata de sujetos adultos que se desenvuelven laboralmente en un ámbito tan exquisito como es el universitario. Esa idea de "corrección" no es más que una reminiscencia del viejo derecho "disciplinario" que debería ser superada. Si se analiza con detenimiento, la corrección parece que sugiere que la sanción disciplinaria debe perseguir "cambiar", "domesticar" al infractor, de forma que a través de ella se consiga modular su pensamiento. No obstante, si el Derecho disciplinario persigue que se cumplan los derechos y deberes presentes en el ámbito universitario, la previsión de la sanción debería perseguir la concienciación de los miembros de la Universidad en la importancia que tienen los bienes jurídicos de su pertenencia para el desarrollo de sus fines y a la par para el bienestar de cada uno de sus miembros (prevención general integradora). Mientras que la imposición de la sanción, una vez fracasada la función de prevención general, debe limitarse a constatar que el sujeto no vuelva cometer en un futuro un comportamiento similar, con independencia de que en su foro interno, piense lo que piense (es decir, con independencia de que se haya "corregido" su comportamiento para el futuro) (prevención especial).

Más fácil es aún recurrir a la idea de “corrección” como finalidad de las sanciones disciplinarias cuando de estudiantes se trata. Si se observa, el Reglamento de 1954 obvia cualquier referencia a la finalidad de la sanción lo que en el marco de aquel "Estado fuerte

\footnotetext{
12 Por todos vid. Eduardo Gamero Casado, Severiano Fernández Ramos, "La potestad sancionadora de las Administraciones públicas", en los mismos, Manual Básico de Derecho Administrativo, ed. Tecnos, Madrid, 2008, pp. 465 y ss; Diego Cámara del Portillo, "El régimen disciplinario del personal al servicio de la Administración universitaria y del alumnado", en Carolina Brasco Delgado (coorda.), Estudios sobre régimen jurídico universitario (Jornada de Secretarios Generales de Universidades públicas), ed. Universidad de Burgos, Burgos, 2006, pp. 185 y ss.
} 
y justiciero"13 no era de extrañar. Sin embargo, la finalidad que se persiga es esencial para, a partir de ella, señalar las conductas constitutivas de infracción y depurar el catálogo de sanciones. En este sentido, el Borrador de Reglamento de Disciplina Académica señalaba en su art. 1 que esa "ley" "tiene por objeto promover la corresponsabilidad y la convivencia en la enseñanza universitaria, impulsar cauces de resolución extraprocesal de conflictos en dicho ámbito y regular los principios y las normas básicas del régimen disciplinario aplicable a las personas integrantes de la comunidad universitaria". Nótese como parece desprenderse la idea de "corresponsabilidad", más que de "corrección". Y esta forma de implicar a los sujetos que forman parte del propio contexto regulado, empoderándolos en él, es una forma mucho más eficaz que otras para evitar infracciones, en la medida en que el alumnado siente la Universidad como propia, y se siente con ella lesionado cada vez que un/a compañero/a copia en un examen, insulta a su docente o causa daños a los bienes materiales $^{14}$.

\footnotetext{
${ }^{13}$ Al que se refería el Preámbulo del Decreto-Ley del 5 de julio de 1938, que reintrodujo en el Código penal español la pena de muerte.

${ }^{14} \mathrm{~A}$ los efectos de limitar el contenido de este trabajo, se dejan a un lado los problemas procesales inherentes a la imposición de las sanciones, a pesar de reconocer que son causantes en muchos casos de inseguridad jurídica. La instrucción es muy delicada, y puede dar lugar a la anulación de pruebas esenciales. Así por ejemplo, es interesante resaltar los incidentes habidos en la STSJ de Andalucía (Sala de lo Contencioso-Administrativo) de 9 de noviembre de 2001 JUR 2002/108113 en la que resuelve el recurso presentado por un profesor a tiempo parcial de la Universidad de Sevilla por una sanción disciplinaria, en la que la información reservada previa al expediente no la llevó a cabo la Universidad de Sevilla, sino la Junta de Andalucía, donde realizaba su segunda actividad. En este sentido, allí se afirma que "en modo alguno puede hablarse de nulidad de pleno derecho por cuanto, al tratarse de una infracción en materia de incompatibilidades no resulta extraño que fuera la Consejería de Gobernación la que iniciara los trámites dirigidos a la averiguación de los hechos y su posible vulneración de la referida normativa. De aquí que se iniciara un expediente informativo que, tras el informe de la Inspección General de Servicios, se remitiera al Rectorado de la Universidad de Sevilla para que fuera éste el que acordara la incoación del procedimiento disciplinario, precisamente el órgano competente para ello". Esto determina que en este caso, por ejemplo, en el procedimiento sancionador intervienen dos administraciones públicas, restando en cualquier caso fuerza a la capacidad de defensa por parte del infractor. Sobre estas cuestiones, vid. María Acale Sánchez, "Como se gesta y como se contrarresta el fraude en la evaluación universitaria", en Revista Rued@, 2015/0, pp. 52 y ss.
} 


\section{II.1.2 Principios que rigen la potestad disciplinaria}

Los principios que rigen la potestad disciplinaria vienen recogidos taxativamente en el art. 94.2 del EBEP y son los de legalidad y tipicidad de las faltas y sanciones, de irretroactividad, proporcionalidad, culpabilidad y presunción de inocencia. Interesa resaltar en este punto que se trata del elenco de principios que recoge la LRJAPPAC (arts. 127 y ss) ${ }^{15}$ como los principios que rigen la potestad sancionadora, aunque llama la atención el hecho de que se haya incluido de forma expresa el principio de culpabilidad que no está incluido de esta forma en la LRJAPPAC ${ }^{16}$.

Pues bien, con tan autoritaria firma, se comprenderse que el Decreto de 1954 obviara la referencia a los principios que rigen la potestad disciplinaria de la Universidad sobre sus estudiantes, lo que no impide sin embargo recurrir a la LRJAPPAC para extender a este ámbito los principios que con carácter general tiene la potestad sancionadora de la Administración pública. Basta la lectura del art. 6 del Decreto de 1954 para constatar la articulación de un catálogo de sanciones esencialmente correctoras: así, allí se llega a confundir el concepto de "sanción" con el de "corrección”, al señalar que "las correcciones aplicables a las faltas de los escolares...".

No obstante, si se tiene en consideración que la Universidad es un ámbito muy sensible, esto es, el ámbito en el que las personas a la vez que adquieren una cualificación

\footnotetext{
${ }^{15}$ Vid. nota 5.

16 La preocupación por limitar el derecho sancionador de la Administración era amplia antes de la aprobación de la LRJAPPAC. EI TS en sentencia de 29 de mayo de 1991 viene a señalar que dado la naturaleza de las sanciones administrativas que pueden llegar a ser igual de graves de las penales: "la capacidad sancionadora de la administración debe ejercerse con estricta sujeción a los principios constitucionales y a los principios del orden penal que son los que han de informar el procedimiento sancionador del ordenamiento administrativo que tiene un fondo o carácter intrínsecamente penal".
} 
y formación profesional, terminan de educarse a sí mismas (y entre ellas mismas) como personas adultas, quizás se debería prestar atención especial a esos principios, para resaltar alguno de ellos sobre otros, o incluso para añadir al elenco alguno más específico. En esta línea, el art. 5 del Borrador de Ley de Convivencia Universitaria establecía como principios básicos a incluir por parte de las Universidades en sus correspondientes "códigos de conductas" los de "responsabilidad personal, ciudadanía democrática, solidaridad, tolerancia, transparencia, participación, pluralismo, diálogo, sentido crítico, reconocimiento de la diversidad y multiculturalismo, capacidad, mérito y esfuerzo, igualdad de oportunidades, respeto a las personas y al entorno, libertad dentro de los principios democráticos que inspiran la convivencia, compromiso con la preservación del medio ambiente, búsqueda de la mejora continua y capacidad de adaptación a los cambios". A estos principios “básicos” se añadían dos catálogos más de "principios éticos" (art. 6 ${ }^{17}$ ) y de "principios de conducta" (art. $7^{18}$ ). Se trata de un

\footnotetext{
${ }^{17}$ Artículo 6. "Principios éticos. Son principios éticos que pueden incluirse por las universidades en sus códigos de conducta los siguientes: 1. Los miembros de la comunidad universitaria ajustarán su actuación con lealtad y buena fe a la Universidad, manteniendo una conducta de colaboración y respeto con las decisiones académicas de carácter organizativo. 2. Su conducta se basará en el respeto a las normas universitarias, a las personas, al entorno, así como a las decisiones de los órganos de gobierno y de representación. 3. Se abstendrán de toda conducta que pueda producir discriminación por razón de nacimiento, origen racial o étnico, sexo, religión, convicción u opinión, edad, discapacidad, nacionalidad, enfermedad, orientación sexual, condición social, y en general cualquier otra forma de discriminación negativa. 4. En la medida de lo posible se facilitarán todas aquellas medidas y actuaciones que favorezcan la integración y plena realización en la vida universitaria de los colectivos
}

más necesitados socialmente. 5. Las relaciones entre los miembros de la comunidad universitaria, atendiendo a sus diferentes sectores, en cuanto a la igualdad de derechos y obligaciones, se ejercerán bajo el principio de responsabilidad compartida. 6. En ningún caso se adoptarán medidas o actuaciones que impliquen privilegios o ventajas injustificadas".

${ }^{18}$ Artículo 7. "Principios de conducta. Son principios de conducta que pueden incluirse por las universidades en sus códigos de conducta los siguientes: 1. El desarrollo de la actividad académica en las debidas condiciones de higiene y seguridad. 2. El respeto de la libertad de conciencia y de las convicciones religiosas, morales o ideológicas. 3. La obtención del mayor provecho y rendimiento de su presencia en las dependencias universitarias donde desarrolle su actividad, de acuerdo con su naturaleza. 4. La utilización de los bienes y recursos de la Universidad de acuerdo con su propia finalidad de servicio público, absteniéndose de utilizarlos para fines distintos en provecho propio, siendo obligación de todos el velar por su conservación. 5. La utilización del nombre y los símbolos universitarios de acuerdo con el procedimiento que se establezca en la normativa de cada Universidad. 6. El respeto y protección de la 
prontuario que con carácter general se articulaban con la finalidad de tutelar la convivencia universitaria, aunque no se incluía un catálogo de principios que rigieran de forma expresa la potestad disciplinaria.

\section{II.1.2.1 El principio de legalidad (tipicidad, irretroactividad y proporcionalidad) y} su corolario de seguridad jurídica

El principio de legalidad en el ámbito administrativo sancionador (del que penden los principios de irretroactividad, tipicidad y proporcionalidad) viene recogido en el art. 25.2 de la Constitución y determina que nadie puede ser sancionado por unos hechos que no hubieran sido tipificados como infracción antes del momento de su realización y solo con las sanciones entonces previstas. En este sentido, la exigencia de legalidad abarca tanto a las conductas constitutivas de infracción como al catálogo de sanciones.

En efecto, si se tiene en consideración el articulado del EBEP, el Título VII regula el "régimen disciplinario" y en su art. 95 clasifica las "faltas" en atención a la gravedad del ataque a los intereses universitarios en muy graves, graves y leves. Tras ello, enumera el catálogo de faltas muy graves ${ }^{19}$. La enumeración no es sin embargo taxativa pues al

libertad de cátedra y de la propiedad intelectual en la realización de trabajos científicos, en función del grado de autoría en su elaboración".

${ }^{19}$ a) El incumplimiento del deber de respeto a la Constitución y a los respectivos Estatutos de Autonomía de las Comunidades Autónomas y Ciudades de Ceuta y Melilla, en el ejercicio de la función pública; b) Toda actuación que suponga discriminación por razón de origen racial o étnico, religión o convicciones, discapacidad, edad u orientación sexual, lengua, opinión, lugar de nacimiento o vecindad, sexo o cualquier otra condición o circunstancia personal o social, así como el acoso por razón de origen racial o étnico, religión o convicciones, discapacidad, edad u orientación sexual y el acoso moral, sexual y por razón de sexo; c) El abandono del servicio, así como no hacerse cargo voluntariamente de las tareas o funciones que tienen encomendadas; d) La adopción de acuerdos manifiestamente ilegales que causen perjuicio grave a la Administración o a los ciudadanos. e) La publicación o utilización indebida de la documentación o información a que tengan o hayan tenido acceso por razón de su cargo o función. f) La negligencia en la custodia de secretos oficiales, declarados así por Ley o clasificados como tales, que sea causa de su publicación o que provoque su difusión o conocimiento indebido. g) El notorio incumplimiento de las funciones esenciales inherentes al puesto de trabajo o funciones encomendadas. h) La violación de la 
final del catálogo se deja abierto a la admisión de nuevas faltas muy graves en la "Ley de las Cortes Generales o de la Asamblea Legislativa de la correspondiente Comunidad o por los convenios colectivos en el caso de personal laboral".

Junto a ellas, el art. 95.3 señala que "las faltas graves serán establecidas por Ley de las Cortes Generales o de la Asamblea Legislativa de la correspondiente Comunidad Autónoma o por los convenios colectivos en el caso de personal laboral, atendiendo a las siguientes circunstancias: a) El grado en que se haya vulnerado la legalidad; b) La gravedad de los daños causados al interés público, patrimonio o bienes de la Administración o de los ciudadanos; c) El descrédito para la imagen pública de la Administración". A ello se añade que "4. Las Leyes de Función Pública que se dicten en desarrollo del presente Estatuto determinarán el régimen aplicable a las faltas leves, atendiendo a las anteriores circunstancias". Si a esto se le une lo dispuesto en el punto 3 de la disposición final cuarta, en virtud de la cual "hasta que se dicten las leyes de función pública y las normas reglamentarias de desarrollo se mantendrán en vigor en cada Administración pública las normas vigentes sobre ordenación, planificación y gestión de recursos humanos en tanto no se opongan a lo establecido en este Estatuto", sigue siendo

\footnotetext{
imparcialidad, utilizando las facultades atribuidas para influir en procesos electorales de cualquier naturaleza y ámbito; i) La desobediencia abierta a las órdenes o instrucciones de un superior, salvo que constituyan infracción manifiesta del Ordenamiento jurídico; j) La prevalencia de la condición de empleado público para obtener un beneficio indebido para sí o para otro; k) La obstaculización al ejercicio de las libertades públicas y derechos sindicales; I) La realización de actos encaminados a coartar el libre ejercicio del derecho de huelga; $m$ ) El incumplimiento de la obligación de atender los servicios esenciales en caso de huelga; n) El incumplimiento de las normas sobre incompatibilidades cuando ello dé lugar a una situación de incompatibilidad; ñ) La incomparecencia injustificada en las Comisiones de Investigación de las Cortes Generales y de las Asambleas Legislativas de las Comunidades Autónomas; o) El acoso laboral; p) También serán faltas muy graves las que queden tipificadas como tales en Ley de las Cortes Generales o de la Asamblea Legislativa de la correspondiente Comunidad Autónoma o por los convenios colectivos en el caso de personal laboral.
} 
necesaria la remisión por una parte al Reglamento de 1986 para los funcionarios públicos y a los Convenios colectivos para el Personal Laboral, lo que causa inseguridad jurídica ${ }^{20}$.

Ha de tenerse en consideración que muchos de estos comportamientos son a su vez constitutivos de delito en los cuales, además la infracción de los deberes del cargo del funcionario es un elemento típico. Esto determina que constatada la violación de esos deberes y producido el comportamiento, el funcionario sea sancionado penal y disciplinariamente aunque en este caso la sanción disciplinaria se producirá con posterioridad a la penal porque en todo caso, los hechos dados por probados por el juez de lo penal han de ser admitidos por la Administración, con el problema añadido de que las medidas cautelares adoptadas administrativamente solo tienen una duración de 6 meses. Transcurrido este plazo, nada impide que sea el juez de instrucción penal el que con el mismo carácter cautelar adopte la misma medida, aunque ahora sí ya será adoptada con los requisitos que exige la Ley de Enjuiciamiento Criminal para el proceso penal correspondiente. Las cuestiones relativas al principio non bis in idem se analizarán posteriormente.

El catálogo de infracciones graves no se señala aunque se tasan los criterios en los que posteriormente, la ley estatal o autonómica o los convenios colectivos para el personal laboral vengan a concretarlas: “a) el grado en que se haya vulnerado la legalidad; b) la gravedad de los daños causados al interés público, patrimonio o bienes de la Administración o de los ciudadanos; c) el descrédito para la imagen pública de la Administración". Con esta técnica se evita violar el principio de legalidad, aunque no se

\footnotetext{
${ }^{20}$ Como también causa esa inseguridad el hecho de que se utilicen a la hora de detallar las infracciones elementos normativos indeterminados como "manifiestamente ilegal", "utilización "indebida", "notorio incumplimiento" que son elementos normativos completamente indeterminados que en primera instancia quedan en manos de la Administración el dotarlos de contenido.
} 
gana en seguridad jurídica. Tampoco se cierra el catálogo de faltas leves, que según el número 4 del art. 95 deja abierto también al posterior desarrollo.

A todo ello ha de unirse que no es pacífica la identificación de las sanciones correspondientes pues si bien el art. $96^{21}$ las detalla, lo deja abierto a "cualquier otra que se establezca por ley". No obstante, no se señala cuáles son las faltas que le corresponde a cada una de las infracciones en atención a su naturaleza y duración.

Por lo que se refiere al principio de legalidad en el ámbito de las infracciones disciplinarias a aplicar al alumnado, puede decirse simplemente que el hecho de que al día de hoy siga en vigor una norma pre-constitucional, es motivo suficiente para constatar el equilibrio que deben hacer las Universidades para actualizar el contenido del catálogo de infracciones allí establecido, reinterpretados a la luz de la Constitución. Obviamente se trata de una tarea que no es imposible, aunque sin duda alguna debería ser llevada a cabo por el legislador, y no caso por caso en las Universidades y por la jurisprudencia. Pero más allá de esos esfuerzos singulares, la cuestión es la propia base del elenco de infracciones que contiene el art. 5 del Decreto de 1954.

Así, con la correspondiente corrección que supone leer su texto desde la Constitución, podemos concluir que son faltas graves: las manifestaciones contra cualquier religión y contra la Constitución ${ }^{22}$; los actos constitutivos de injurias, ofensas o

\footnotetext{
21 “Por razón de las faltas cometidas podrán imponerse las siguientes sanciones: a) Separación del servicio de los funcionarios, que en el caso de los funcionarios interinos comportará la revocación de su nombramiento, y que sólo podrá sancionar la comisión de faltas muy graves; b) Despido disciplinario del personal laboral, que sólo podrá sancionar la comisión de faltas muy graves y comportará la inhabilitación para ser titular de un nuevo contrato de trabajo con funciones similares a las que desempeñaban; c) Suspensión firme de funciones, o de empleo y sueldo en el caso del personal laboral, con una duración máxima de 6 años; d) Traslado forzoso, con o sin cambio de localidad de residencia, por el período que en cada caso se establezca; e) Demérito, que consistirá en la penalización a efectos de carrera, promoción o movilidad voluntaria; f) Apercibimiento; g) Cualquier otra que se establezca por Ley. 2. Procederá la readmisión del personal laboral fijo cuando sea declarado improcedente el despido acordado como consecuencia de la incoación de un expediente disciplinario por la comisión de una falta muy grave".

${ }^{22}$ Esta infracción se correspondería con la letra a) "Ias manifestaciones contra la Religión y moral católicas o contra los principios e instituciones del Estado" del Decreto de 1954.
} 
falta de consideración hacia el resto de miembros de la comunidad universitaria ${ }^{23}$; la suplantación de personalidad en actos académicos, así como la falsificación de documentos $^{24}$; la reiteración de faltas menos graves ${ }^{25}$.

De este catálogo se ha eliminado el número 5 del art. 5 del Decreto de 1954, en el que se establece que es constitutiva de infracción grave "la falta de probidad y las constitutivas de delito". La falta de probidad, si no es constitutiva de una falsedad, no debe ser rechazable con una sanción y en su caso debería ser una faceta del estudiante a desarrollar. Por otra parte, considerar constitutiva de infracción grave la comisión de un delito, de cualquier delito, carece de razón. En su caso, podría hacerse alguna referencia a delitos cometidos en el ámbito universitario pero más que para considerarlo directamente una conducta constitutiva de infracción grave, para valorar su tratamiento desde el punto de vista del principio non ibis in idem que impide la doble sanción a igualdad de hecho, sujeto y fundamento y si ese delito no incide en la vida universitaria, tampoco debe ser objeto de reproche universitario. Esta infracción es analizada detenidamente en la STS (Sala de lo Contencioso Administrativo) de 7 de junio de 1999 [RJ/1999/5018]. La defensa alegaba que no sabía si los estudiantes habían sido condenados en atención al número 5 de la letra a) del art. 5 del Decreto -“falta de probidad y las constitutivas de delito"- porque hubieran faltado a la verdad o por haber cometido un delito. E1 TS en su Sentencia señala que "el mismo Tribunal Constitucional había admitido en su sentencia número 50/1983, de 14 de junio (RTC 1983, 50), la «tipificación necesariamente genérica de las faltas muy graves de probidad», cuya aplicación a una persona sometida a relaciones de dependencia especial y conocedora

\footnotetext{
23 "La injuria, ofensa o insubordinación contra las autoridades académicas o contra los Profesores".

${ }^{24}$ Que más o menos se corresponde con lo dispuesto en el número 4 del art. 5 del Decreto de 1954.

${ }^{25}$ Número 6.
} 
del régimen jurídico que las regula no vulnera la garantía constitucional invocada (al margen otros problemas de rango de la norma sancionadora, que aquí no son del caso)".

Se mantiene la reiteración de faltas menos graves, en virtud de lo establecido en la LRJAPPAC a pesar de los riesgos de estar centrando la atención más que en la responsabilidad por el hecho, en las características del autor.

Las infracciones menos graves establecidas en la letra b) del art. 5, tras el correspondiente proceso de actualización a la luz de los principios que deben regir la actuación sancionadora de la Administración deberían quedar reducidas a la perturbación del orden necesario para el desarrollo de las actividades docentes, de investigación y de gestión de la Universidad y a la reiteración de faltas leves. En efecto, el resto de conductas allí incluidas, al día de hoy carecen de razón. Así, la $1^{\text {a }}$-“las palabras o hechos indecorosos o cualesquiera actos que perturben notablemente el orden que debe existir en los establecimientos de enseñanza, dentro o fuera de las aulas"- es una infracción que no puede mantenerse por vacía de significado, por violadora del principio de legalidad y por autoritaria. La misma suerte debe seguir la $2^{\mathrm{a}}$-"la resistencia, en todas sus formas, a las órdenes o acuerdos superiores"- pues lo importante no es la desobediencia, sino el efecto negativo que causa en la convivencia. La número $3^{a}$-“la falta de asistencia a clase y los demás hechos comprendidos en los números anteriores cuando tengan carácter colectivo"- debe ser doblemente rechazada: en primer lugar, porque en un modelo de enseñanza en el que se potencia la capacidad del estudiante para formarse y se le convierte en sujeto activo del proceso de enseñanza, en puridad de principios, la "asistencia a clase" puede llegar a ser una obligación que no encaja con el nuevo prontuario; pero además, porque la responsabilidad debe ser en cualquier caso individual, y cualquier atisbo de responsabilidad colectiva no es más que una muestra de un derecho disciplinario que ignora el principio de culpabilidad en sus distintas acepciones. Esto determina la 
inconstitucionalidad de lo dispuesto también en el art. 9, en el que se deduce el carácter colectivo de las infracciones.

Finalmente, las infracciones leves deben ser completamente reinterpretadas a la luz del catálogo de principios que inspiren la potestad sancionadora de la Universidad: en efecto, la letra

c) considera infracción leve "cualesquiera otros hechos no comprendidos en los apartados anteriores que puedan causar perturbación en el orden o disciplina académicos". El mero hecho de que no exista un catálogo de principios dentro del propio Decreto de 1954 desde el cual poder interpretar las infracciones muy graves y las graves, hace muy difícil la tarea de concretar con un mínimo de certeza jurídica el de las leves.

Con carácter general ha de resaltarse que se trata en el mejor de los casos de un elenco de figuras ilícitas vacuas, que se centran más en el desvalor de acción que en el desvalor de resultado que producen y en el marco de un derecho disciplinario que parta del principio del hecho, el desvalor de acción debe pasar a un plano secundario, de forma que no fundamente sino que en todo caso, sirva como criterio de graduación de la infracción y de la correspondiente sanción.

Frente a esta parquedad y falta de orientación del catálogo de infracciones en el Decreto de 1954, el Borrador de Ley de convivencia incluía unos catálogos de infracciones muy graves ${ }^{26}$,

\footnotetext{
${ }^{26}$ Son faltas muy graves: a) La realización de actos que atenten contra los valores democráticos o que promuevan la xenofobia, que sean negadores del holocausto o de crímenes contra la humanidad o que hagan apología del terrorismo; b) La realización de actos que impidan un correcto desarrollo de los procesos electorales en la Universidad. c) El acoso reiterado, de cualquier naturaleza, a los miembros de la comunidad universitaria; d) La agresión de palabra u obra, así como la falta de respeto muy grave a cualquier miembro de la comunidad universitaria o de empresas subcontratadas, tanto docentes como no docentes. e) La realización de novatadas que supongan grave menoscabo del honor, la dignidad o la personalidad del agredido. f) La distribución de sustancias estupefacientes y sicotrópicas en el ámbito universitario; g) El plagio, en todo o en parte, de obras intelectuales de cualquier tipo; h) La posesión en el recinto universitario de armas u objetos peligrosos; i) Las denuncias manifiestamente falsas contra otros individuos de la comunidad universitaria; j) La suplantación de un profesional en la realización de su labor
} 
propia en actividades universitarias, ya sea dentro o fuera de las instalaciones de la Universidad y sus dependencias; $k$ ) La suplantación de personalidad en actos de la vida académica o el beneficiarse de ésta; l) Apoderarse por cualquier medio fraudulento o por abuso de confianza del contenido de una prueba, examen o control de conocimiento, en beneficio propio o ajeno, antes de su realización; o una vez realizada la evaluación procurar la sustracción, alteración o destrucción de fórmulas, cuestionarios, notas o calificaciones, en beneficio propio o ajeno. m) La interceptación en el ámbito universitario de comunicaciones privadas. n) La interceptación de correos electrónicos o su distribución cuando haya sido prohibido por el remitente. o) La condena en sentencia firme por cualquier ilícito penal constitutivo de delito o falta contra otro miembro de la comunidad universitaria, o contra los bienes y derechos de la Universidad o de empresas subcontratadas. p) La oposición violenta a la celebración de actos académicos o al cumplimiento de las disposiciones universitarias. q) La entrada no autorizada en los sistemas informáticos de la Universidad; la perturbación de su funcionamiento; la modificación o la utilización fraudulenta de archivos electrónicos. r) La falsificación, sustracción o destrucción de documentos académicos o la utilización de documentos falsos ante la Universidad. s) Toda actuación que suponga discriminación por razón de nacimiento, origen racial o étnico, sexo, religión, convicción u opinión, edad, discapacidad, nacionalidad, enfermedad, orientación sexual e identidad de género, condición socioeconómica, idiomática o lingüística, o afinidad política y sindical, o por razón de apariencia, sobrepeso u obesidad, o por cualquier otra condición o circunstancia personal o social, de los miembros de la comunidad universitaria, del personal de las entidades colaboradoras o que presten servicios en la Universidad t) La reiteración de tres faltas graves. 
graves $^{27}$ y leves ${ }^{28}$, centradas más en los hechos que en el autor, además de actualizarse a

las novedades que la ciencia ha incorporado a la vida universitaria diaria. De su contenido

\begin{abstract}
${ }^{27}$ Son faltas graves: a) Obstaculizar la celebración de actos académicos, salvo en aquellos casos en los que la conducta se pueda justificar por el ejercicio de algún derecho fundamental. b) Incumplir las normas sobre seguridad a la hora de participar en las actividades formativas, especialmente aquellas que supongan la manipulación de sustancias peligrosas; a) Mutilar las obras que componen el patrimonio bibliográfico de la universidad, o deteriorar dicho patrimonio, incluyendo la sustracción de volúmenes. c) Realizar conductas vejatorias de la institución universitaria o de los miembros que la integran que no sean susceptibles de ser consideradas como faltas muy graves; d) Alterar reiteradamente la circulación de bienes y personas por el recinto universitario; e) Realizar cualquier comportamiento atentatorio contra la salubridad e higiene que cause perjuicio manifiesto a los demás miembros de la comunidad universitaria o dificulte la convivencia; f) Actuar para pretender o conseguir falsear o defraudar los sistemas de comprobación del rendimiento académico, tanto si es beneficiario de los mismos como cooperador necesario. g) Estar en estado de embriaguez o bajo los efectos de drogas en el recinto de la Universidad.
\end{abstract}

h) Cometer tres faltas leves. i) No participar reiteradamente y sin justificación en los órganos de gobierno de la Universidad para el que haya elegido. b) No acudir a las mesas electorales a las que haya sido designado. c) Distribuir a través de las redes electrónicas de la universidad material que pueda ser ofensivo para el destinatario.

d) Utilizar los sistemas informáticos de la Universidad para la realización de actos

contrarios a la propiedad intelectual, incluyendo la descarga de archivos amparados por ésta. e) Deteriorar grave e intencionadamente el patrimonio universitario o de otros miembros de la comunidad universitaria o de terceros cuando se estén

desarrollando actividades universitarias. f) Incumplir la normativa de residuos en aquellos casos en los que así se pueda considerar por la naturaleza de los mismos.

g) Entrar dolosamente en aquellas instalaciones universitarias para las que resulte

necesario estar especialmente autorizado. h) Permanecer en las habitaciones de los colegios mayores y residencias universitarias de titularidad de la Universidad habiendo cesado el derecho a su ocupación, cuando medie requerimiento de desalojo y no sea atendido. i) Utilizar sin previa autorización las instalaciones y recursos de la Institución para otros fines que no sean los directamente relacionados con la actividad académica universitaria del estudiante, aún cuando de dicha utilización no se obtuviesen beneficios económicos o de cualquier otro tipo a favor del infractor. j) Realizar actos que alteren el conocimiento por parte de la Universidad de la situación socioeconómica del estudiante y que le permita obtener un beneficio social o económico.

${ }^{28}$ Artículo 20. Faltas leves. Serán faltas leves a la convivencia universitaria: a) La ejecución de actividades que perturben mínimamente de forma leve el funcionamiento normal de la Universidad, de alguno de sus servicios o de los centros adscritos a ella. b) La realización de actos que causen deterioro no grave del patrimonio universitario o de otros miembros de la comunidad universitaria o de terceros cuando se estén desarrollando actividades universitarias. c) El consumo de tabaco en el recinto universitario en el que esté prohibido de acuerdo con la legislación general aplicable. d) El incumplimiento de la normativa de residuos, en aquellos casos en que por la naturaleza de los productos no pueda ser considerada falta grave. e) El deterioro de menor cuantía del patrimonio bibliográfico de la universidad, con independencia de la reglamentación del servicio universitario. f) La utilización de los servicios universitarios sin el abono de los precios que estén establecidos. g) La inasistencia reiterada a las actividades formativas que den lugar a la obtención de una titulación de carácter oficial con validez en todo el territorio nacional. 
puede decirse que la violación del principio de legalidad no solo se produce cuando no existe un desarrollo legislativo, o cuando hay que recurrir haciendo malabares a normas de carácter preconstitucional para -tamizadas desde la lupa constitucional-adaptarlas al momento actual: también se vulnera dicho principio cuando se recurre por falta de precisión a conceptos vagos, amplios o tan sumamente descriptivos que dejan la aplicabilidad de la norma al servicio de la ideología del intérprete. Esto es lo que ocurriría si se empleara para describir una infracción los elementos normativos indeterminados como "manifiestamente ilegal", "utilización indebida", "notorio incumplimiento": más aún si se usan conjuntamente para describir una misma infracción ${ }^{29}$.

Todos estos problemas de identificación de las conductas constitutivas de infracción administrativa vienen a poner en peligro el principio de legalidad. Esta cuestión ha sido esgrimida en distintas ocasiones ante los tribunales. En cualquier caso, convence el razonamiento de la STSJ de Galicia (Sala de lo Contencioso Administrativo) 259/2004, de 31 de marzo con este argumento:

Esta Sala ya ha tenido ocasión de rechazar dicho argumento en la sentencia decisoria del recurso núm. $1067 / 96$ en la que se razonó que el carácter preconstitucional del Reglamento de Disciplina Académica, aprobado por Decreto de 8 de septiembre de 1954, no implica sin más que haya quedado derogado por la Disposición Derogatoria $3^{a}$ de la Constitución dado el alcance que el artículo 25 atribuye a la llamada reserva de Ley, ni puede ser tachado de inconstitucional. Así tuvo ocasión de establecerlo el Tribunal Supremo (en sentencias de 12 de diciembre de 1986 y 11 de abril de 1989 [ RJ 1989, 3343]) al señalar reiteradamente que, si bien la sanción impuesta al recurrente no tiene la cobertura legal exigida por el artículo 25.1 CE, cuenta sin

\footnotetext{
${ }^{29}$ Véase el anteriormente citado art. 20 del Borrador de Ley.
} 
embargo con el requisito de la tipificación contenida en una norma preconstitucional, esto es, en el Decreto de 8 de septiembre de 1954, y reitera la STS de 7 de marzo de 2002 ( $R J$ 2002, 5077) que es reiterada, consolidada y uniforme la doctrina jurisprudencial que declara que no es posible exigir la reserva de Ley de manera retroactiva para anular disposiciones reguladoras de materias y situaciones respecto de las cuales tal reserva no existía de acuerdo con el Derecho anterior a la Constitución, o, dicho sea en otros términos, que el principio de legalidad que se traduce en la reserva absoluta de Ley, no incide en disposiciones o actos nacidos al mundo del derecho con anterioridad al momento en que la Constitución fue promulgada. Distinto sería que la sanción se apoyase en normas carentes de cobertura legal habilitante nacidas con posterioridad a la Constitución, en cuyo caso, por no guardar las prescripciones exigidas por el citado artículo 25.1 sí harían factible el éxito de la pretensión actora. De la doctrina, del Tribunal Constitucional (sentencias de 8 de abril de 1981 [RTC 1981, 11] y 21 de enero de 1987 [RTC 1987, 2]) se desprende que no se puede interpretar tan estrictamente el principio de reserva de Ley que impida la tipificación de infracciones y sanciones por un Reglamento anterior al texto constitucional, máxime si con posterioridad una norma con rango legal atribuye en la materia a la Administración la potestad sancionadora. Un Reglamento preconstitucional no exigiría la legalidad habilitante para aquella tipificación, sin perjuicio de que sus normas hayan de interpretarse con arreglo a los principios emanados del texto constitucional, re interpretación constitucional sin necesidad de derogación que ha sido admitida en la STC de 7 de noviembre de 1988 (RTC 1988, 204), entre otras muchas. 
El artículo 27-3 de la LRU, proporciona la necesaria habilitación legal postconstitucional al permitir a las Universidades establecer las normas que regulen las responsabilidades de los estudiantes.

\section{II.1.2.3 El principio non bis in idem}

Nada dice el EBEP en torno a la vigencia del principio non bis in idem en esta sede. Es más, las pocas previsiones que contiene van en la línea opuesta. Así, cuando afirma en el art. 94 que la sanción administrativa se impondrá “sin perjuicio de la responsabilidad patrimonial o penal que pudiera derivarse de tales infracciones", se deduce la compatibilidad de ambas sanciones. Sí se hace mención expresa sin embargo a los efectos procesales de ese principio. Así el art. 94.3 establece que "cuando de la instrucción de un procedimiento disciplinario resulte la existencia de indicios fundados de criminalidad, se suspenderá su tramitación poniéndolo en conocimiento del Ministerio Fiscal", disposición que ha de ser complementada con lo establecido en el art. 98.3, en virtud del cual "se podrán adoptar mediante resolución motivada medidas de carácter provisional que aseguren la eficacia de la resolución final que pudiera recaer".

Si se pasa a analizar ahora el Decreto de 1954 sobre la responsabilidad disciplinaria de los estudiantes, como se decía anteriormente, se considera infracción muy grave la comisión de un hecho constitutivo de delito (art. 5.a.5). Con ello, al margen ya de las referencias realizadas anteriormente en relación con este punto, debe tenerse en consideración que ha de recurrirse a las pautas generales de la LRJAPPAC para todo lo referido al principio non bis in idem.

La previsión final del art. 94.1 EBEP, en lo que a la extensión de la responsabilidad disciplinaria se refiere - esto es, aquella parte del precepto que establece 
que esa responsabilidad se va a exigir "sin perjuicio de la responsabilidad patrimonial o penal que pudiera derivarse de tales infracciones"- es de máxima relevancia y constata la preeminencia del Derecho administrativo sancionador, que convive con sanciones de naturaleza civil y penal en el marco de los límites que impone el principio non bis in idem que es el principio cierre del ordenamiento jurídico. Procesalmente, el núm. 3 del art. 94 añade que "cuando de la instrucción de un procedimiento disciplinario resulte la existencia de indicios fundados de criminalidad, se suspenderá su tramitación poniéndolo en conocimiento del Ministerio Fiscal". El precepto guarda silencio en torno a la adopción de medidas cautelares, aunque nada impedirá recurrir al art. 136, que permite el traslado al orden penal con las medidas cautelares que se hayan adoptado.

La autoridad judicial ha de resolver. Si condena por un delito contra la Administración pública, y si el total del desvalor administrativo es tenido en cuenta por el precepto penal, la Administración no podrá imponer sanción disciplinaria alguna. Si por el contrario, el juez en su sentencia entiende que no existe responsabilidad penal, dará traslado de todo lo actuado a la Administración por si los hechos fueran constitutivos de infracción disciplinaria. En este caso, la Administración tendrá que dar por válidos los hechos que el juez haya estimado como probados en el orden jurisdiccional (art. 133 LRJAPPAC).

La STS (sala de lo Penal) 534/2011, de 10 de junio, RJ/2011/4671 examina el caso de un Profesor titular de la Universidad de Valencia que entró en varias ocasiones en las cuentas de correo electrónico oficial de varios compañeros del Departamento. El TS entiende que no hay un delito contra la intimidad y le absuelve, pero no se condiciona la existencia de otros ilícitos disciplinarios:

\footnotetext{
" $Y$, en efecto, no es así, ya que la atribución al acusado de la conducta descrita en los
} 
hechos, cuenta con el sustento de las pruebas de cargo que se relacionan en los seis apartados del primer fundamento de derecho de la sentencia, en los que se toma en consideración las declaraciones inculpatorias de los ahora acusadores particulares y otros, así como otras periciales, que, al contrario de lo que sucede con las que se invoca como fundamento de este motivo, examinaron directamente los equipos sobre los que dictaminan, los servidores de la Universidad y la documentación que existe en la causa .... De este modo, tanto por la inidoneidad técnica del planteamiento del motivo, como porque los hechos de la sentencia cuentan con un soporte probatorio mucho más atendible que los que darían sustento a la hipótesis de la defensa, el motivo debe rechazarse".

Por su parte, analiza los efectos procesales del principio non bis in idem la STSJ de Castilla y León (Sala de lo Contencioso-Administrativo) 2033/2012, de 27 de noviembre, en la que se examina la sanción disciplinaria impuesta por la Universidad de Salamanca a una profesora "de suspensión de funciones por un periodo de tres meses y se ordena su cumplimiento entre los días 15 de noviembre de 2011 y 15 de febrero de 2012”. En su recurso se alega indefensión porque se ejecutó la sanción antes de que fuera firme la sentencia de lo Contencioso Administrativo. La interesada alega que "al haberse procedido a la ejecución de la sanción antes de que pudiese pronunciarse sobre sus eventual suspensión la administración de justicia, y en concreto el Juzgado de lo Contencioso-Administrativo de Salamanca, se infringió el derecho de la actora a tal derecho. El TSJ afirma que "ha de indicarse que dicho indudable beneficio para el administrado queda sometido a la carga para el mismo de así solicitarlo poniendo en conocimiento de la administración la impugnación o la voluntad de hacerlo. Tal carga procesal no consta que se haya cumplido en el presente caso por la actora, quien agotó 
el plazo que para promover el proceso judicial establece el ordenamiento, sin llevar a cabo tal actividad en sede administrativa, lo que impide que pueda considerarse que impute a otro el perjuicio por ella sufrida y que solo a su falta de diligencia le puede ser atribuida. Recuérdese que en nuestro derecho administrativo sancionador, el principio es el de la ejecutividad de las resoluciones que ponen fin a la vía administrativa y sin necesidad de "autorización judicial" alguna para ello. Por lo tanto, habrá de señalarse que, incumplida la obligación por quien puede beneficiarse de la suspensión, no puede dolerse válidamente de su falta de diligencia”.

\section{II.1.2.3 El principio de culpabilidad}

En su primera acepción, puede entenderse que la culpabilidad es lo contrario a inocencia, con lo cual poco aportaría la inclusión dentro del art. 94 del EBEP si por tal hubiera que entenderse eso, pues el mismo artículo en su letra e) se refiere expresamente al "principio de presunción de inocencia". Bajo esa referencia, se quiere hacer resaltar el principio de personalidad de la infracción y de la sanción ${ }^{30}$. Así, afirma la STSJ de Castilla La Mancha (Sala de lo Contencioso-Administrativo, Sección 1 ${ }^{\text {a }}$ ) Sentencia n. 533/2000 de 23 mayo RJCAl2000\2024 que ese principio "se aplica al ámbito administrativo sancionador, que implica que la carga de la prueba de los hechos constitutivos de la infracción recaiga sobre la Administración (STC 197/1995 [RTC 1995, 197]; 4/1997 [RTC 1997, 4] ; 3/1999, de 26 de enero [RTC 1999, 3])”.

La jurisprudencia administrativa también ha admitido la acepción del principio de culpabilidad como reprochabilidad o capacidad de motivación por la norma, a pesar de que tampoco está expresamente reconocida por la LRJAPPAC. Así, la STSJ de Andalucía

\footnotetext{
${ }^{30}$ En este sentido, ya la STS, 3ạ , de 3 mayo de 1988 no cabe sanción administrativa "cuando ni tan siquiera se ha demostrado suficientemente la autoría del ilícito.
} 
(Sala de lo Contencioso-Administrativo) de 19 de octubre de 1999_RJCA\1999\4883 ${ }^{31}$ afirma que "la Constitución consagra sin duda el principio de culpabilidad como principio estructural básico del Derecho Penal. Este principio rige también en materia de infracciones administrativas, pues en la medida en que la sanción de dicha infracción es una de las manifestaciones del Derecho Punitivo del Estado, resulta inadmisible en nuestro ordenamiento un régimen de responsabilidad objetiva o sin culpa. El elemento de la culpabilidad en toda infracción supone un presupuesto básico determinado por la imputabilidad, entendida como capacidad general de entender y querer en relación con los hechos que suponen la infracción y la culpabilidad en sí misma considerada como el juicio de reproche que a través del Orden Jurídico y del Estado hace la Sociedad de la infracción cometida. Por supuesto que en el hoy recurrente concurría el elemento de la culpabilidad sin que pueda eximirle de su responsabilidad su propia creencia subjetiva”.

Por su parte, la STS $3^{\text {a }}$ de 8 de junio de 1984 excluye la responsabilidad administrativa en los casos en los que se actúa bajo una amenaza real "en el momento de cometer tales omisiones las personas que incidieron en ellas se hallaban bajo una amenaza real que les privó de libertad y voluntad en su actuación, lo cual les exonera de responsabilidad". De esta forma, si en la responsabilidad administrativa la intencionalidad es una circunstancia a tener en cuenta en la graduación de la sanción eso significa que la responsabilidad administrativa es una responsabilidad objetiva. Efectivamente, el art. 130.1 LRJAPPAC afirma que solo podrán ser sancionadas por hechos constitutivos de infracción administrativa las personas físicas y jurídicas que resulten responsables de los mismos aun a título de simple inobservancia. Así, se ha afirmado que en la esfera del Derecho Administrativo no se requiere una conducta dolosa, sino simplemente irregular (STS, 3 $3^{\mathrm{a}}, 22$ de abril de 1985); que la voluntariedad del

\footnotetext{
${ }^{31}$ Violación del deber de abstenerse según la LRJPA catedrático de universidad que examina a su hija.
} 
resultado de la acción no es elemento constitutivo de la infracción administrativa (STS, $3^{\text {a }}, 15$ de julio de 1985) y que "a diferencia de la tipicidad del orden penal, en la infracción sancionable de carácter administrativo no es factor constituyente de la culpabilidad salvo los excepcionales supuestos que así lo establezca la norma tipificante o la requiera la misma índole de los hechos sujetos, en principio a responsabilidad objetiva".

Por todos los riesgos que conlleva esta tendencia objetivista, se ha desarrollado una línea doctrinal y jurisprudencial (SSTS, 3ª 21 septiembre 1982, 7 febrero 1987, 16 de mayo de 1977) en apoyo de integrar este elemento culpabilístico en la definición del injusto administrativo. De ahí que el EBEP lo mencione expresamente.

Por su parte, varias son las previsiones de carácter general que establece el EBEP en torno a los sujetos responsables de los ilícitos disciplinarios. Así, el núm. 2 del art. 93 establece que "los funcionarios públicos o el personal laboral que indujeren a otros a la realización de actos o conductas constitutivos de falta disciplinaria incurrirán en la misma responsabilidad que éstos". Esta cláusula de extensión de la responsabilidad disciplinaria se acompaña en el número $3^{\circ}$ de una segunda en virtud de la cual, “igualmente, incurrirán en responsabilidad los funcionarios públicos o personal laboral que encubrieren las faltas consumadas muy graves o graves, cuando de dichos actos se derive un daño grave para la Administración o los ciudadanos". Esto es tanto como afirmar que responden administrativamente los autores, los inductores y los encubridores aunque con diferencias entre ellos. Así, la sanción que le corresponda al inductor será la misma que la del autor, mientras que la responsabilidad del inductor se limita a los casos de faltas consumadas muy graves o graves, solo si de las mismas se deriva un daño "grave" para la Administración o los ciudadanos. En puridad de principios, cabe entender que siempre que se afecte a la Administración, se está también afectando a los ciudadanos. 
Quizás lo que el precepto quiere señalar más que cualquier ciudadano es que se trate de un ilícito que haya dañado particularmente a una persona.

Particular relevancia tiene la responsabilidad de todos esos sujetos por comportamientos omisivos. En este sentido, será considerado sujeto activo de una infracción no solo el autor material, y quien le hubiera inducido o encubierto, sino también quien teniendo obligación de actuar, no haya impedido que el autor siguiera cometiendo el ilícito (por ejemplo, si detectada un uso irregular de dinero, el Gerente no hace nada por evitarlo). La vía de la responsabilidad administrativa en comisión por omisión puede abrir las puertas del derecho sancionador considerablemente ${ }^{32}$.

Por su parte, el Decreto de 1954 también contiene una serie de pautas sobre los autores de los ilícitos disciplinarios. El art. 7 establece que "los que indujeren a la comisión de una falta incurrirán en la corrección señalada para la misma, aunque no se hubiere consumado", dando por hecho una vez más que lo importante en el contexto de este autoritario decreto es el desvalor de acción, más que el de resultado. Y en este marco,

\footnotetext{
32 Puede verse la STSJ de Castilla-La Mancha, (Sala de lo Contencioso-Administrativo, Sección 1â) Sentencia n. 533/2000 de 23 mayo RJCA $2000 \backslash 2024$ en la que se le imputan a un catedrático de Universidad omisiones "consistentes en no prestarle a doña Inmaculada O. G., en su condición de Profesora Ayudante de Escuela Universitaria, ni ayuda ni orientación científica; y obstaculizarle en el libre acceso y el uso de los materiales, la bibliografía y los equipos informáticos del área a la Profesora O., en aplicación de lo establecido en el art. 20, del Reglamento de Régimen Disciplinario". Si bien en instancia la Universidad le consideró autor de una falta grave y le sanción con tres meses de suspensión, el TSJ le absuelve por violación del principio de tipicidad: "El tipo sancionador señala literalmente la necesidad de "grave perturbación", esto es, el trastorno o desviación, en este caso, de la vida departamental de forma grande, de mucha entidad o importancia (Véase, en este sentido, la conceptuación gramatical de dichos términos en el Diccionario de la Real Academia Española); alteración intensa o importante que sólo puede quedar definida por el alcance mismo de la perturbación o lo que es lo mismo, por el resultado lesivo". Y en el presente caso, no cabe duda que los hechos no constituyeron una perturbación del servicio público, ya que no supuso ni existe constancia alguna que implicara una paralización o alteración forzada o violenta de la vida del área o departamento". Previamente se deja sentando que la profesora en cuestión había realizado sus cursos de doctorado en la UNED y allí tenía su tesis inscrita y su director, de forma que "desde un inicio ya tenía definida su orientación científica y tutoría esencial fuera de la esfera del ámbito de la responsabilidad de don Alfredo".
} 
por lo que toca al Decreto de 1954, puede comprenderse que la admisión de infracciones colectivas, vulnera el principio de personalidad de la infracción.

\section{II.1.3 Las sanciones a imponer}

El catálogo de sanciones que establece el EBEP es el genérico para el personal de las Administraciones públicas, lo que significa que paralelamente tasa las sanciones, pero deja el catálogo abierto: separación del servicio de los funcionarios; despido disciplinario para el personal laboral; suspensión de funciones, o de empleo y sueldo en el caso de personal laboral; traslado forzoso con o sin cambio de localidad de residencia; demérito; apercibimiento y termina el listado con la admisión de "cualquier otra que se establezca por ley". Se trata de un listado muy cerrado y con pocas posibilidades de adaptar la sanción a las características del caso concreto. Lo único que añade el art. 96.3 es que " $e l$ alcance de cada sanción se establecerá teniendo en cuenta el grado de intencionalidad, descuido o negligencia, la reiteración o la reincidencia, así como el grado de participación". Este régimen sancionador no permite dar entrada al principio de oportunidad, que pueda tamizar según los casos la imposición y/o ejecución de la correspondiente sanción, por ejemplo a través de mecanismos de suspensión de la misma si durante un plazo el sancionado no vuelve a cometer infracción y respeta unas pautas de conductas impuestas.

Esa falta de imaginación se reproduce con mayor virulencia en el catálogo de sanciones a imponer a los/as estudiantes. Si se lleva a cabo una lectura de dicho catálogo a la luz de los principios que rigen el orden sancionador contemplados en la Constitución, cabe concluir, que dicho catálogo quedaría reducido a las siguientes sanciones: así, para las infracciones, no quedaría otra que la expulsión temporal, en la medida en que las 
sanciones perpetuas deben entenderse eliminadas de nuestro ordenamiento jurídico. Para las infracciones menos graves, la "prohibición de examinarse de la totalidad o parte de las asignaturas en que se encuentre matriculado, en todas las convocatorias del año académico, con la consiguiente pérdida de los derechos de matrícula", no parece plantear ningún problema de constitucionalidad; respecto a la devolución de las cantidades obtenidas en concepto de beca quizás debería someterse a un análisis pues las becas se condicionan a unos rendimientos académicos y por tanto en atención a ellos se debería, en su caso, prever la devolución de las cantidades, pero no por otros motivos como pudiera ser la comisión de una infracción disciplinaria. Obviamente si se impone la sanción de imposibilidad de examinarse en una asignatura y/o curso becado, se estarán incumpliendo los requisitos que cada año exige el Decreto Becas para justificar la ayuda recibida en atención a lo dispuesto en la Ley General de Subvenciones. Y respecto al catálogo de las sanciones leves, debería quedar reducido a la pérdida de matrícula de algunas asignaturas y la amonestación (pública o privada).

En cualquier caso, el carácter antipedagógico de la mayor parte de estas sanciones es indudable (por ejemplo, pérdida del derecho a asistir a clases).

Quizás al día de hoy y visto el fracaso de este catálogo de sanciones, pueda pensarse en otras más variadas que afecten directamente al contenido de la relación que se establece en la Universidad, que tengan un carácter pro-universitario, es decir, que estén orientadas a formar al estudiante: horas de estancia en biblioteca, trabajos en beneficio de la Universidad, multa proporcional/día multa, alejamiento, acercamiento, suspensión del derecho a examen, y expulsión -temporal/definitiva-, reservado esta última para los casos más graves ${ }^{33}$.

\footnotetext{
${ }^{33} \mathrm{Y}$ se regule de alguna forma el acceso a otras Universidades.
} 


\section{PROPUESTAS DE LEGE FERENDA}

Como CEDU queremos aprovechar la coyuntura política en la que nos encontramos, con un proceso electoral en marcha, y dirigirnos a los Partidos Políticos que concurren a las mismas a fin de instar su compromiso con la Universidad y particularmente, con el desarrollo de políticas activas que impulsen la convivencia pacífica. Con esta finalidad, le instamos a que aprueben el Reglamento de desarrollo del Estatuto del Estudiante Universitario en materia disciplinaria, sobre la base de un Decálogo de principios sobre ética universitaria a partir del cual levantar el catálogo de infracciones y de las correspondientes sanciones, así como sobre el procedimiento de imposición y de los sujetos participantes.

Así mismo, queremos instarles a que confieran formalmente a la mediación el papel de alternativa al proceso disciplinario; al acuerdo de mediación, el de alternativa a la sanción, y a las Defensorías universitarias el papel de impulsores de los acuerdos de mediación y reparación.

\section{LISTADO SENTENCIAS ANALIZADAS}

\section{PERSONAL DE LA UNIVERSIDAD}

1. Sentencia del Juzgado de lo Social de Vitoria 29/2012, de 26 de enero AS/2012/1805: acoso sexual (absolución por juzgado)

2. STS (sala de lo Penal) 534/2011, de 10 de junio, RJ/2011/4671: Profesor titular de la Universidad de Valencia (delito contra la intimidad: se absuelve en sede penal, pero no se condiciona la existencia de otros ilícitos disciplinarios) 
3. STSJ Andalucía (Sala de lo Social) 1601/2009, de 24 de septiembre JUR/2013/243418: profesor asociado de la Universidad de Málaga

4. STSJ de Valencia (Sala de lo Contencioso-Administrativo) 208/2015, de 17 de marzo: profesor titular de escuela Universitaria de la Universidad de Valencia

5. STSJ de Castilla y León (sala de lo Social) 826/2992, de 1 de octubre, AS 2002/2751: profesor de Universidad Privada (SEK de Segovia: despido disciplinario de profesores por falta de lealtad con la empresa)

6. STSJ Castilla y León (Sala de lo Contencioso-Administrativo) 2226/2014, de 31 de octubre (Profesora Titular de Escuela Universitaria de la Universidad de Valladolid: fundamento de la potestad sancionadora de la Administración. Derecho de petición)

7. STSJ Castilla y León (Sala de lo Contencioso-Administrativo) 833/2014, de 25 de abril JUR 2014/156050 (Profesora Titular de escuela universitaria de la Universidad de Valladolid).

8. STSJ Castilla y León (Sala de lo Contencioso-Administrativo) 2033/2012, de 27 de noviembre JUR/2013/2930, Universidad de Salamanca (no se puede identificar si el sujeto activo es PAS o PDI)

9. STSJ de Galicia (Sala de lo Contencioso-Administrativo) 153/2014, de 12 de marzo JUR/2014/214209 (Profesor Titular de la Universidad de Santiago)

10. STSJ de Galicia (Sala de lo Social) 2547/2011, de 3 de mayo JUR/2011/207677 (Universidad de Santiago de Compostela, PAS: conductor sustituto sancionado por desconsideración a superior pero en virtud del Convenio colectivo del Pas laboral: hay que estar a sus cláusulas, en vez de por el EBEP)) 
11. STSJ de Madrid (Sala de lo contencioso) 69/2013, de 30 de enero JUR/2013/103372 (Profesor Universidad Complutense)

12. STSJ de Andalucía (Sala de lo Contencioso-Administrativo) 465/2001, de 2 de julio (Profesor de la Universidad de Granada)

13. STSJ Castilla La Mancha (Sala de lo Contencioso-Administrativo) 533/2000, de 23 de mayo RJCA/2000/2024 (Catedrático de Universidad de la Universidad de Castilla La Mancha condenado en instancia por omitir apoyo y ayuda a una profesora ayudante y absuelto en sentencia).

14. STSJ de Madrid, (Sala de lo Contencioso-Administrativo) de 26 septiembre 2002 JUR 2003\153053 (Catedrático de la Universidad Complutense: no existe incumplimiento de obligaciones docente cuando el profesor tiene una comisión de servicios)

15. STSJ de Andalucía (Sala de lo Contencioso-Administrativo) de 19 de octubre de 1999 RJCAl1999\4883: violación del deber de abstenerse según la LPA catedrático de universidad que examina a su hija.

16. STSJ de Madrid (Sala de lo Contencioso-Administrativo) de 26 de septiembre de 2002, JUR 2003/153053

17. STSJ de Andalucía (Sala de lo Contencioso-Administrativo) de 9 de noviembre de 2001 JUR 2002/108113 (Profesor titular a tiempo parcial de la Universidad de Sevilla: incumplimiento de la ley de incompatibilidades porque a pesar de tener reconocida la compatibilidad genérica, no pidió la específica para dirigir unas obras). 


\section{ESTUDIANTES}

19. 1. STSJ País Vasco 559/2014, de 10 de diciembre, inseguridad jurídica: estudiantes: régimen disciplinario: falta muy grave: insubordinación contra las autoridades académicas o contra los profesores: negativa del alumno a abandonar el aula cuando había sido instado a hacerlo: infracción existente; falta grave: palabras o hechos indecorosos: ofensas para los aludidos o los destinatarios: infracción existente; sanción: principio de proporcionalidad: vulneración existente: reducción procedente.

20. 2. STSJ Murcia, 100/2013, 15 febrero RJCA 2013/339, amonestación pública, híbridos (becario de investigación que es estudiante e insulta a otro estudiante en el Consejo de Estudiantes).

21. 3. STS 7 de marzo 2002 RJ 2002/5077, suplantación de personalidad sanción de expulsión de la Universidad de Sevilla.

22. 4. STSJ Galicia 259/2004, 31 de marzo, JUR 2004/260143 sanción de expulsión de 3 años. Se alega violación del principio de legalidad por el carácter preconstitucional del Decreto de 1954. El Tribunal rechaza esta argumentación.

23. 5. STSJ Galicia 1393/2001, 14 noviembre, JUR 2002/41791 colegios mayores

24. 6. STSJ Extremadura 239/1998, de 16 de marzo, RJCA 1998/986 suplantación de personalidad en un examen.

25. 7. STSJ Navarra 66/1996, de 21 de diciembre RJCA 1996/2596.

26. 8. STSJ País Vasco 212/2014, de 7 de mayo, JUR 2014/232856: injuria, ofensa o insubordinación contra las autoridades académicas o contra los profesores: sanción procedente: expulsión: proporcionalidad.

27. 9. STSJ Cataluña 131/2000, de 5 de diciembre, JUR 2001/110896 (se deniega la medida cautelar solicitada por la Universidad de expulsión de estudiante de 
Facultad de Derecho que lesiona a su profesor delante del resto de sus compañeros, ponderando los daños que sufre el estudiante y los que sufre la Universidad.

28. 10. STS 9 de julio 2001, RJ 2001/7772, UNED (alumno sancionado en instancia por copiar en un examen; esa sanción posteriormente se anula porque los hechos habían prescritos. Parece que los hechos dieron lugar simultáneamente a la apertura de unas diligencias previas - penales- por comisión de delito de falsedad)

29. 11. STS de 15 de diciembre de 2000 RJ/2000/9853 (Universidad de Sevilla) alumnos expulsados de la Universidad por entrar sin la debida autorización, en un Departamento; introducirse en los despachos de sus profesores a pesar de que al menos uno de ellos estaba cerrado y sustraer los exámenes.

30. 12. STS de 7 de junio de 1999, RJ 1999/5018 (Universidad Complutense) alumna sancionada disciplinariamente con un año de expulsión por usar pinganillo en un examen.

31. 13. STS de 23 de julio de 1993 RJ/1993/6204 (Universidad Complutense).

32. 14. STSJ Madrid 1140/1999, de 10 de noviembre RJCA 1999/4876 (UNED).

33. 15. SAP Málaga 126/2004, de 16 de marzo, ARP\2004\404 estudiante de la UNED (condena por delito contra la Administración de Justicia y sanción disciplinaria de expulsión de la Universidad por hechos que pueden ser analizados de forma separada. 